\title{
PENGGUNAAN PUPUK CAIR EKSTRAK LIMBAH RUMAH TANGGA DALAM BUDIDAYA ORGANIK KEDELAI PADA SISTEM AGROFORESTRI
}

\author{
Siti Mardhikasari ${ }^{1)}$, Djoko Purnomo ${ }^{2)}$ dan Triyono D.S. ${ }^{2)}$ \\ ${ }^{1)}$ Mahasiswa Program Studi Agroteknologi Fakultas Pertanian UNS \\ ${ }^{2)}$ Program Studi Agroteknologi Fakultas Pertanian UNS \\ Email: djpuruns@gmail.com
}

\begin{abstract}
Abstact
Organic cultivation in egroforestry system by biofertilizer potentialy conducted for soybean. Soybean cultivation in agroforestry system there are several limitations but it have to effort since the area of ideal land decreasing year by year. The aim of the research by experiment method is increasing yield of soybean by organic cultivation in agrofrestry system either quality or quantity. The experiment design is randomized block design (RBD) with two factor trearments. The first factor are kinds of variety (Grobogan and Local) as mainplot and the second one are biofertilizer duration (no biofertilizer as control, 4, 5, 6, 7 weeks applies ones a week). So there are 10 combination treatments and replicated three times for each of them.
\end{abstract}

Keywords: Agroforestry, Biofertilizer, Soybean.

\section{PENDAHULUAN}

Perkembangan sistem agroforestri sudah semakin jauh namun teknologi budidaya belum sepenuhnya terkuasai. Sistem agroforestri berpotensi sebagai sarana peningkatan hasil tanaman baik secara kuantitatif maupun kualitatif, sebagai penyedia pangan sehat (budidaya organik) dari pertanian sehat (Hairiah 2003) dan berwawasan lingkungan (Budiastuti dan Purnomo 2012). Kedelai adalah bahan pangan penting di Indonesia selain padi dan jagung. Bahan pangan berasal dari pengolahan kedelai sangat variatif (Erlina et al. 2009) seperti tempe, tahu, susu kedelai, dan pakan ternak dan karena peningkatan jumlah penduduk maka kebutuhan semakin besar. Dengan kebutuhan kedelai setiap kapita 8,12 kg (Sudaryanto dan Swastika 2007), padahal produksi dalam negeri masih terbatas (hanya 800000 ton per tahun), maka impor kedelai berkisar 1,5-1,8 juta ton (Departemen Pertanian 2003). Peluang peningkatan hasil kedelai secara ekstensif melalui sistem agroforestri sangat besar (berbasis jati dan pinus) (Purnomo dan Sitompul 2005) namun perlu pengembangan teknologi mengatasi hambatan seperti cahaya (Purnomo et al. 2013) dan pemupukan yang mengacu pada pertanian berkelanjutan dan keamanan pangan (Utomo 2010). Sebagai lahan budidaya sistem agroforestri dapat mencegah degradasi tanah sebagai akibat dari eksploitasi hutan (Mayrowani dan
Ashari 2011) dan mewujudkan budidaya tanaman sehat (Hairiah 2003).

Budidaya organik kedelai dalam sistem agroforestri dalam rangka menjaga keamanan pangan dan pertanian sehat, dapat menggunakan berbagai pupuk ramah lingkungan seperti pupuk hayati, kompos, dan pupuk organik cair. Pupuk hayati antara lain nitragin (Simanungkalit et al. 2006), biakan Azospirilium brasilense, Azospirilium lipoferum, dan Azospirilium amazonense (Sutanto 2002), dan powder yang mengandung Azotobacter sp., Azospirillum sp., Lactobasillus sp., Bacillus sp., Aspergillus $s p$., Trichoderma $s p$. yang dilengkapi: unsur makro dan mikro, senyawa bioaktif, hormon pertumbuhan, vitamin, dan anti hama hayati. Kompos meskipun di hutan cukup tersedia bahan (seresah pohon dan gulma) namun dalam praktek terkendala oleh keperluan bahan dalam volume besar dan proses yang relatif lama. Berdasarkan hal itu penggunaan pupuk organik cair berupa ekstrak yang berasal dari fermentasi berbagai bahan organik dapat dikembangkan. Penggunaan pupuk organik cair dalam sistem agroforestri untuk budidaya tanaman khususnya kedelai memerlukan kajian agar diperoleh informasi yang lebih akurat.

Larutan mikroorganisme lokal (MOL) merupakan salah satu aktivator yang dapat mempercepat ketersediaan pupuk. Larutan MOL dapat diperoleh dari limbah rumah tangga ataupun industri yang diolah melalui fermentasi sebagai sumber bakteri. Larutan 
MOL mengandung unsur mikro dan makro, serta bakteri yang berpotensi sebagai perombak bahan organik, perangsang tumbuhan, dan sebagai agens pengendali hama serta penyakit tanaman (Purwasasmita 2009). Larutan MOL dapat diperoleh dari limbah berbagai buah sebagai perangsang pengisian bulir padi, daun gamal untuk perangsang pertumbuhan daun, bonggol pisang untuk dekomposer saat pembuatan kompos, limbah sayuran untuk merangsang pertumbuhan malai, dan rebung untuk merangsang pertumbuhan tanaman, serta masih banyak macam MOL yang lain (Purwasasmita dan Kunia, 2009). Keuntungan pupuk organik cair adalah: larutan tidak pekat (maksimum 5\%), menyediakan hara sesuai kebutuhan tanaman, jika berlebihan tanaman secara otomatis mengatur penyerapan, pemupukan lebih merata, dan tidak terjadi akumulasi di satu lokasi karena seluruh bahan terlarut. Oleh karena itu pupuk organik cair secara cepat mengatasi defesiensi hara, tidak mengalami pencucian, dan cepat menyediakan hara (Musnamar 2006).

Berdasarkan uraian diatas dilakukan penelitian sehingga memperoleh informasi tentang: potensi kedelai varietas Galunggung dalam sistem agroforestri Gunung Gajah, potensi penggunaan pupuk cair berasal dari fermentasi limbah rumah tangga, dan teknologi panggunaan pupuk cair.

\section{METODE PENELITIAN}

Penelitian dengan percobaan diselenggarakan dari bulan April sampai dengan Agustus 2013 di Desa Gunung Gajah, Kecamatan Cawas, Kabupaten Klaten dengah posisi geografi $7^{\circ} 46^{\prime} 7,2^{\prime \prime}$ LS dan $110^{\circ} 39^{\prime}$ 34,5" BT, elevasi $208 \mathrm{~m}$ dpl., dan jenis tanah litosol. Rancangan percobaan adalah rancangan acak kelompok (RAK), kedelai varietas Galunggung yang diberi perlakuan durasi pemberian pupuk cair ( 0 sebagai kontrol dan 4, 5, 6, serta 7 minggu, diberikan setiap minggu), setiap perlakuan diulang 3 (tiga) kali. Sebelum penanaman dilakukan analisis tanah dan pupuk kandang tentang kandungan $\mathrm{N}, \mathrm{P}, \mathrm{K}, \mathrm{pH}$, dan bahan organik (BO).

Tanah diolah menggunakan cangkul sedalam 20-30 cm, sebagai satuan percobaan adalah petak berukuran $2,0 \times 1,20 \mathrm{~m}$. Penanaman sebanyak 4 biji setiap lubang tanam (dibuat dengan tugal) berjarak $20 \times 20$ $\mathrm{cm}$, lubang kemudian ditutup dengan pupuk kandang dosis sekitar 5 ton ha ${ }^{-1}$ sebagai pupuk dasar dan starter pupuk organik cair (POC). Setelah tanaman berumur 7 hari diperjarang menjadi 2 tanaman per lubang. Pemeliharaan berupa penyiangan (setiap minggu), pengairan dengan gembor (setiap tiga hari jika tidak turun hujan), dan pengendalian pengganggu (setiap 14 hari secara manual). Pupuk organik cair dibuat dengan cara menampung limbah rumah tangga (sisa: sayur dan nasi baik sudah dimasak atau mentah, buah, dan bumbu) diperam (fermentasi) selama seminggu, cairan yang keluar ditampung sebagai POC dasar. Pupuk organik cair digunakan dengan konsentrasi 1,51 POC per 151 air dengan cara menyiramkan pada tanah.

Variabel penelitian berupa: kondisi cahaya (menggunakan lux meter), sifat tanah (kelembaban dengan higrometer Sauna, $\mathrm{pH}$ dengan $\mathrm{pH}$ meter, $\mathrm{N}$ tersedia dengan metode Kjeildahl, $\mathrm{P}$ dengan metode Bray, $\mathrm{K}$ tersedia, C organik, dan KTK), pertumbuhan vegetatif yang diamati secara destruktif pada umur 15 , 30, dan 45 hari sehingga diperoleh bobot biomassa (akar, batang, dan daun) yang dipergunakan untuk menghitung Indeks Luas Daun (ILD), Luas Daun Spesifik (LDS), Harga Satuan Daun (HSD), dan Laju Pertumbuhan Absolut (LPA), serta jumlah bintil akar, pertumbuhan generatif, antara lain: jumlah dan berat polong isi dan hampa, bobot seratus biji, bobot biji, dan indeks panen. Data yang diperoleh melalui analisis ragam diperoleh uji $\mathrm{F}$ taraf 0,05 , jika berbeda nyata dilanjutkan dengan uji jarak berganda Duncan (Duncan Multiple Range Test/DMRT), dan uji korelasi, serta regresi.

\section{HASIL DAN PEMBAHASAN}

\section{Kondisi air dan tanah}

Kawasan agroforestri tempat penelitian berbasis berbagai tegakan pohon, antara lain pisang, mangga, mahoni, dan jati dengan jarak sekitar 3 x 3 m, dengan curah hujan 141,43 $\mathrm{mm}$ per tahun, tidak tersedia irigasi (lahan tadah hujan). Kawasan berbukit-bukit (kemiringan 25-30\%), dengan kandungan bahan organik $0,92 \%$ (sangat rendah), kadar $\mathrm{N}$, P, dan K-tersedia masing-masing $0,06 \%$ (rendah), 4 ppm (rendah), dan 0,04 me $100^{-1} \mathrm{~g}$ (rendah), sehingga tingkat kesuburan termasuk kategori rendah. Agregasi tanah litosol belum 
optimum menandakan bahwa proses pedogenesis tanah belum lanjut. Ini ditunjukkan oleh kelas tekstur geluh berdebu (Silty Loamy), kadar C organik dan bahan organik rendah, persentase fraksi klei dan bahan organik juga rendah berakibat pada proses sementasi agregat tanah rendah. Kondisi tersebut mengakibatkan keadaan hidrologi daerah ini masuk dalam kategori kritis (Purnomo et al. 2012).

\section{Intersepsi cahaya dan pertumbuhan tanaman}

Cahaya yang lolos dari tajuk atau kanopi pohon menentukan pertumbuhan tanaman dalam sistem agroforestri dan peran karakter kanopi sangat besar (Purnomo et al. 2013). Rerata cahaya yang lolos dari kanopi pisang, mangga, mahoni, dan jati yang diterima oleh kanopi kedelai hanya sekitar 22,0\% dari 49000 lux. Selanjutnya cahaya tersebut diintersep oleh kedelai sesuai dengan pertumbuhan tanaman. Oleh karena itu intersepsi cahaya dapat digunakan sebagai indikator pertumbuhan. Kedelai kontrol berumur 15 hari setelah tanam (hst), intersepsi cahaya dengan panjang masa pemupukan berkorelasi negatif dan rendah (r: - 0,2), selanjutnya analisis regresi menunjukkan peran pupuk relatif juga rendah $\left(\mathrm{R}^{2}: 0,4\right)$, yang berarti saat itu tanggapan tanaman terhadap POC masih rendah (sebagian besar masih bergantung pada ketersediaan hara dalam tanah dan pupuk kandang). Saat kedelai berumur 30 hst korelasi antara intersepsi cahaya dan durasi pemupukan sangat erat (r: 0,95), analisis anova juga berbeda nyata dan peran pupuk terhadap intersepsi cahaya sangat besar $\quad\left(R^{2}: 0,92\right)$. Korelasi kedua hal tersebut dan peran pemupukan terhadap ontersepsi cahaya masih cukup besar saat tanaman mencapai umur 45 hst (r: 0,8 dan $\mathrm{R}^{2}$ : 0,6) (gambar 1A). Bila dihubungkan dengan habitus tanaman yang tercermin pada karakter daun yang dinyatakan dengan indeks luas daun (ILD), tanaman mengintersep cahaya 50, 90, dan 95\% mencerminkan ILD sebesar 1,0, 3,3, dan 4,3 (Sinclair and Gardner, 1998). Ini berarti bahwa ILD kedelai di penelitian ini hanya sekitar 1,0 (hasil pengukuran ILD tertinggi juga hanya 1,0) menandakan pertumbuhan tidak optimum karena cahaya diterima tanaman sangat rendah (hanya 22,0\%). Ini berati jauh dari ILD optimum bagi tanaman pertanian sebesar 3-5 (Sitompul dan
Guritno, 1995). Pemberian pupuk organik meningkatkan pertumbuhan kedelai (berdasarkan intersepsi cahaya) dan mencapai optimum dengan pemberian sebanyak 6 kali (6 minggu dengan penyiraman setiap minggu). Ini dapat dijelaskan bahwa efektifitas pemupukan melalui daun pada kedelai terjadi pada saat menjelang pertumbuhan konstan hingga mencapai konstan, sesuai pendapat Suharto (2010), bahwa masa vegetatif kedelai berlangsung sejak tanaman ditanam sampai umur 5 minggu atau 35 hst.

Selain ILD kinerja daun tercermin juga pada luas daun spesifik (LDS) yang menandakan tebal daun. Korelasi antara pemberian durasi pupuk berkorelasi negatif dengan LDS, yang berarti daun semakin tebal dengan semakin panjang durasi pemupukan (umur 15, 30, dan 45 hst, nilai koefisien korelasi (r) masing-masing adalah - 0,77, - 0,92, dan - 0,76). Melalui uji regresi peran panjang durasi pemupukan terhadap LDS mengikuti model linier dengan $\mathrm{R}^{2}$ umur 15 , 30, dan 45 hst masing-masing 0,60, 0,85, dan 0,57 (gambar 1B). Ini memperkuat argumen di atas bahwa respon tanaman terhadap durasi pemupukan, saat umur 15 hari, rendah kemudian meningkat sesuai peningkatan umur. Tebal daun berkorelasi dengan kandungan khlorofil dan enzim (Taiz and Zieger, 2010), dengan demikian juga berhubungan dengan potensi fotosintesis. Fotosintat terbagi: menjadi bahan kering (biomassa), sebagai senyawa antara pembentuk molekul lain, dan energi bagi pertumbuhan (Taiz and Zieger, 2010). Daun semakin tebal potensi fotosintesis juga semakin besar terefleksikan dalam bobot biomassa. Bobot biomassa kedelai sejak berumur 15, 30, dan 45 hst berkorelasi positif dengan durasi pemberian POC, nilai $r$ sekitar 0,70. Analisis regresi menunjukkan bahwa peran durasi pemupukan terhadap bobot biomassa cukup besar $\left(\mathrm{R}^{2}\right.$ : berkisar 0,5) (gambar 1C). Bobot biomassa tertinggi dicapai oleh tanaman dengan durasi pemupukan selama 6 minggu (diberikan setiap minggu) saat mencapai pertumbuhan maksimum (umur 45 hst) sebesar 4,4 g per lubang tanam. Penelitian Purnomo, dkk. (2011) pada tempat berdekatan memperoleh bobot biomassa lebih tinggi, demikian juga lebih rendah dibanding tanaman dalam sistem agroforestri berbasis jati dan pinus (8-14 g per lobang tanam (Purnomo dan Sitompul, 2006). Cahaya rendah yang diterima oleh kedelai menjadi penyebab bobot 
biomassa rendah karena fotosintesis jauh dibawah optimum.

Kedelai selalu bersimbiosis dengan rhizobium yang tercermin dalam bintil akar. Penelitian di agroforestri berbasis jati (Purnomo, 2014), sebelumnya tidak ditanami legume (jumlah bintil akar efektif hanya 4,9 per tanaman), di sini jumlah bintil akar efektif lebih besar (sekitar 9,0 hingga 11,0 per tanaman) saat tanaman berumur 30 hst kemudian turun sehubungan semakin tua. Jumlah bintil akar tidak berbeda nyata pada semua durasi pemupukan. Pertumbuhan dan perkembangan rhizobium berlangsung baik karena tanah tempat menanam kedelai pernah ditanami kedelai dan pemberian pupuk kandang sebesar 5 ton ha $^{-1}$ menyediakan $\mathrm{N}$.

\section{Komponen produksi dan produksi}

Biji kedelai terletak didalam polong yang terbentuk setelah bunga melakukan penyerbukan. Periode pengisian polong memerlukan kondisi tertentu yang bila tidak terpenuhi terjadi gangguan sehingga polong gagal berbiji atau hampa. Jumlah polong isi pada kedelai varietas Galunggung menunjukkan bahwa peran durasi pemupukan POC sangat besar (nilai r: 0,97, $\mathrm{R}^{2}$ : 0,9). Durasi penggunaan POC semakin lama berakibat pada daun yang semakin tebal yang berarti potensi fotosintesis makin besar. Akibat selanjutnya adalah bobot biomassa juga semakin besar, berarti pertumbuhan makin baik, pengisian polong berlangsung baik maka jumlah polong isi makin besar sedangkan jumlah polong hampa makin rendah. Jumlah polong isi berisikan 2 sampai 4 biji tercerminkan dalam berat biji juga sesuai dengan peran POC $\left(R^{2}\right.$ juga 0,9$)$ (gambar $\left.1 D\right)$. Pembahasan diatas dengan analisis regresi menunjukkan bahwa durasi penggunaan POC selama 7 minggu belum mencapai optimum. Namun bila durasi diperpanjang dengan pemberian setiap minggu, tanaman sudah menua sehingga kurang efisien. Oleh karena itu durasi diperpanjang dengan memperpendek rentang waktu pemberian (kurang dari seminggu).

Bobot biji tertinggi dicapai oleh kedelai sebesar 3,31 g per lubang tanam (dua tanaman) yang setara dengan sekitar 0,83 ton ha $^{-1}$ (jarak tanam $20 \times 20 \mathrm{~cm}$ ) pada tanaman dipupuk POC selama 7 minggu. Ini lebih rendah dari deskripsi kedelai varietas Galunggung sebesar 1,5 ton ha ${ }^{-1}$ bahkan juga lebih randah dari rerata nasional sebesar 1,0 ton $\mathrm{ha}^{-1}$ ), namun lebih tinggi daripada hasil kedelai budidaya organik menggunakan kompos di Wonogiri (0,6 ton ha $\left.{ }^{-1}\right)$ (Purnomo, 2014). Bobot 100 biji juga lebih rendah daripada deskripsi (11,66 berbanding $12,5 \mathrm{~g}$ ), yang berarti biji lebih kecil akibat dari cahaya rendah sehingga akumulasi fotosintat juga tidak optimum. Di Probolinggo (Jatim) kuantitas hasil kedelai ditentukan oleh jumlah polong, bobot 100 biji, dan jumlah biji, di Banyuwangi ditentukan oleh tinggi tanaman, jumlah polong, dan jumlah biji, sedang di Malang ditentukan oleh umur masak, jumlah polong, dan jumlah biji (Susanto dan Adie, 2006). 

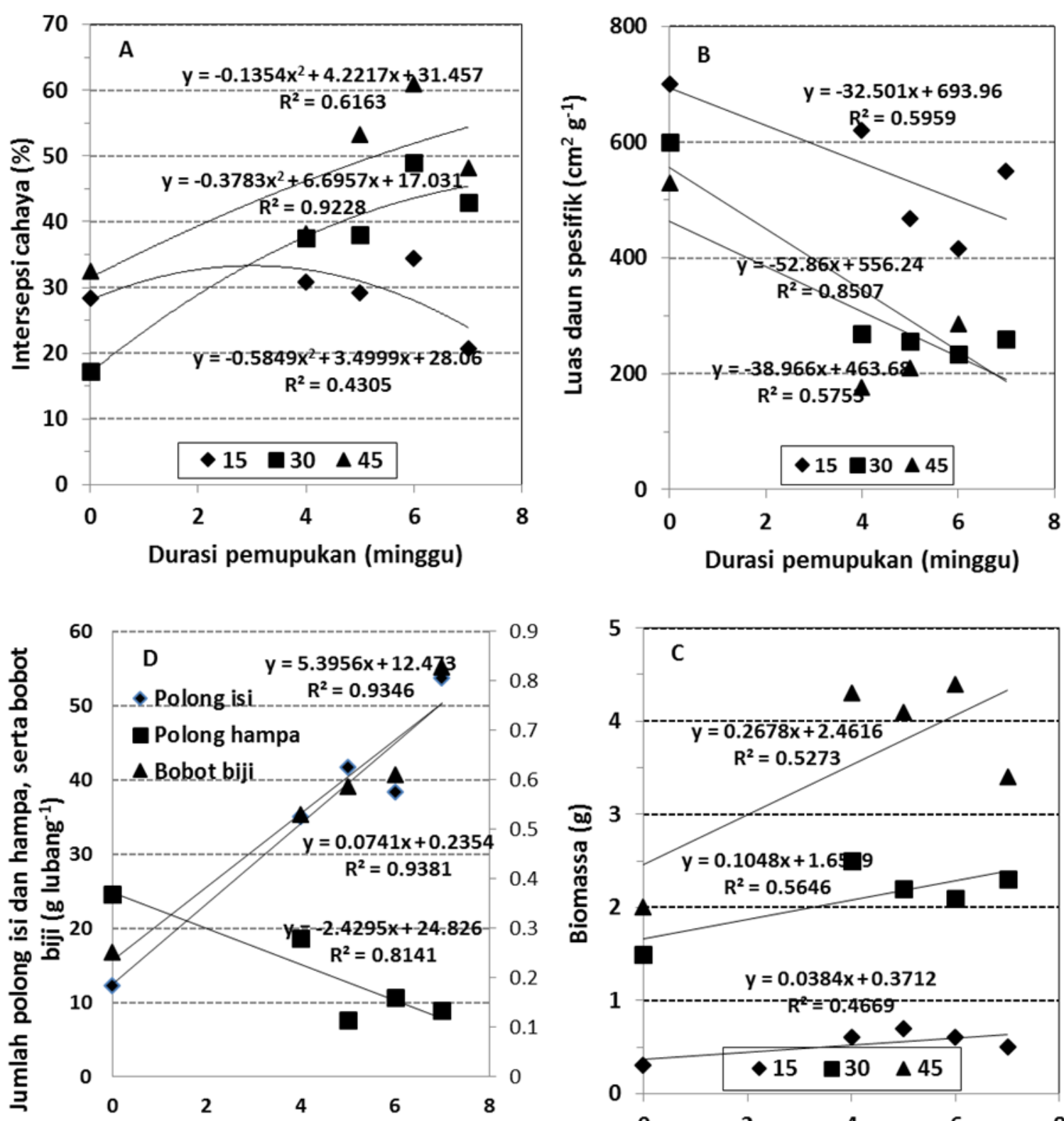

Durasi pemupukan (minggu)

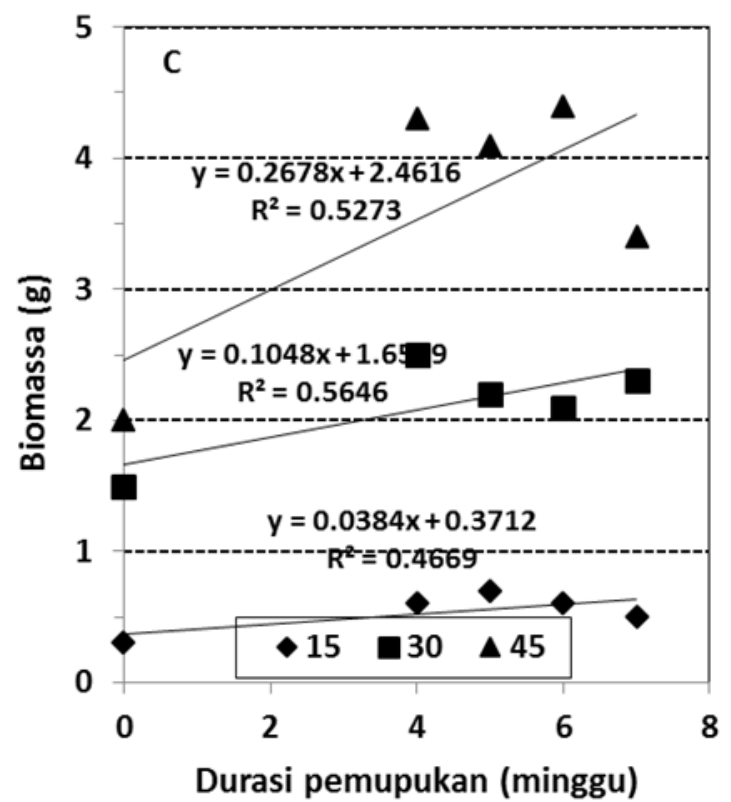

Gambar 1. Peran durasi pupuk organik cair terhadap A. intersepsi cahaya, B. luas daun spesifik, C. biomassa, dan $\mathrm{D}$. jumlah polong isi dan hampa serta bobot biji.

\section{KESIMPULAN}

Lahan hutan berbasis aneka pohon potensial sebagai pertanaman kedelai budidaya organik sistem agroforestry. Cahaya diterima kedelai sebesar $22 \%$ dan penggunaan pupuk organik cair $(1,51 / 151$ air $)$ diberikan perminggu selama 7 minggu berturut-turut mencapai hasil 0,83 ton hä ${ }^{-1}$.

\section{UCAPAN TERIMAKASIH}

Terimakasih yang tak terhingga disampaikan kepada Bapak Diyono.

\section{DAFTAR PUSTAKA}

Andrianto T.T dan Indarto 2004. Budidaya dan Analisis Usaha Tani: Kedelai, Kacang Hijau, Kacang Panjang. Absolut. Yogyakarta.

Black C and C Ong 2000. Utilization of light and water in tropical argiculture. Agricultural and Forest Meteorology 1004:25-47.

Budiastuti, S. dan D. Purnomo. 2012. Agroforestri. bentuk pengelolaan lahan 
berwawasan lingkungan. Sebelas Maret University Press.

Budi G.P dan Oetami D.H 2008. Kemapuan kompetisi beberapa varietas kedelai (Glycine max) terhadap gulma alangalang (Imperata cylindrica) dan teki (Cyperus rotundus). Artikel Ilmiah. Universitas Muhammadiyah Purwokerto.

Chusnia W, Tini S, Salamun 2012. Kajian pupuk hayati dalam meningkatkan pertumbuhan dan produksi tanaman kacang hijau (Vigna radiata L.) pada polybag. http://biologi.fst.unair.ac.id/wpcontent/uploads/2012/04/jurnal-

Wilda.pdf. Diakses pada tanggal 4 Juni 2013.

Departemen Pertanian. 2003. Database Departemen Pertanian. Jakarta.

Didik S, Kurniatun H, Nurheni W, Sunaryo, Meine VN 2003. Bahan ajaran agroforestri 4: peran agroforestri pada skala plot: analisis komponene agroforestri sebagai kunci keberhasilan atau kegagalan pemanfaatan lahan. Bogor: World Agroforestry Centre (ICRAF).

Hairiah, K. 2003. Agroforestri: Tawaran menuju pertanian sehat dalam M.S. Sabarnurdin, S. Hardiwinoto, S. Danarto dan P. Suryanto (editor) Peranan Strategis Agroforestri dalam Pengelolaan Sumberdaya Alam Secara Lestari dan Terpadu. Prosiding Seminar Nasional Agroforestri. UGM. Jogjakarta. hal 47-64

Kastono D 2005. Tanggapan pertumbuhan hasil kedelai hitam terhadap penggunaan pupuk organik dan biopestisida gulma siam (Chromolaena odorata). Ilmu Pertanian Vol. 12 No. 2, 2005: 103-116

Kemal 2001. Tentang budidaya pertanian: kedelai (Glycine $\max$ L). Jakarta: Menteri Riset dan Teknologi.

Kurniansyah D 2012. Produksi kedelai organik panen kering dari dua varietas kedelai dengan berbagai jenis pupuk organik. Laporan Penelitian. IPB Bogor.

Lukitasari M 2012. Pengaruh intensitas cahaya matahari terhadap pertumbuhan tanaman kedelai (Glycine max). IKIP PGRI Madiun.
Mayrowani H dan Ashari 2011. Pengembangan agroforestri untuk mendukung ketahanan pangan dan pemberdayaan petani sekitar hutan. Forum Penelitian Agro Ekonomi Vol. 29 No. 2, Desember 2011: 83-98.

Meirina T, Sri D, Sri H 2012. Produktivitas kedelai (Glycine $\max$ L. Merril var. Lokon) yang diperlakukan dengan pupuk organik cair lengkap pada dosis dan waktu pemupukan yang berbeda. Laporan Penelitian. Jurusan Biologi Fakultas Matematika dan Ilmu Pengetahuan Alam Universitas Diponegoro.

Purnomo D dan S.M Sitompul 2005. Evaluasi potensi dan kendala pengembangan sistem agroforestri di Jawa Tengah. Habitat 4 (3): 197-207.

Purnomo D dan Sitompul S.M. 2006. Irradiasi pada sistem agroforestri berbasis jati dan pinus serta pengaruhnya terhadap pertumbuhan tanaman kedelai. Biodiversitas Vol. 7 No. 3: 251-255. 2006.

Purnomo D, Suryono, Trijono DS, Mth Sri Budiastuti, and Supriyadi. 2012. Varies litter containing tannin on agroforestry system as nitrification inhibitor for increasing nitrogen fertilizer effisiency for soybean. J. of Agriculture Sience and Technology B, 2 (2): 198-203.

Purnomo, D. dan Sitompul S.M., dan Budiastuti S. MTh. 2013. Solar radiation in agroforestry system. J. Of Agricultural Science and Technology B. Vol. 3 No. 8: 351-356.

Purnomo, D. 2014. Potensi budiadaya tanaman kedelai organik pada berbagai sistem agroforestri. Laporan Penelitian. Fak. Pertanian UNS.

Rosiana, N. 2013. Bobot akar dan bobot bintil akar efektif-non efektif kacang gude (Cajanus cajan) pada budidaya dengan pemupukan berbagai jenis sumber fosfat. Skripsi IKIP PGRI Semarang.

Rusmiati, Gani, dan Susilowati 2005. Pengaruh jarak tanam dan saat pemberian pupuk SP-36 terhadap pertumbuhan dan hasil tanaman kedelai (Glycie $\max (\mathrm{L})$. Merill) varietas anjasmoro. Jurnal 
Budidaya Pertanian Vol. 11 No. 2: hal 72-79.

Salisbury F.B dan Ross C.W 1992. Plant Physiology. Wadsworth Publishing. Company Belmont, California.

Simanungkalit, Didi AS, Rasti S, Diah S, Wiwik H 2006. Pupuk organik dan pupuk hayati. Balai Besar Penelitian dan Pengembangan Sumberdaya Lahan Pertanian. Bogor.

Sumarsono 2008. Analisis kuantitatif pertumbuhan tanaman kedelai. Jurusan Nutrisi dan Makanan Ternak Fakultas Peternakan Universitas Diponegoro.

Susanto, G.W.A. dan M.M. Adie. 2006. Sidik lintas dan implikasinya pada seleksi kedelai. peningkatan produksi kacangkacangan dan umbi-umbian mendukung kemandirian pangan. Balai Penelitian dan Pengembangan Pertanian. Pusat Penelitian dan Pengembangan Tanaman
Pangan Departemen Pertanian. Bogor. 914.

Sutanto R 2002. Penerapan Pertanian Organik: Pemasyarakatan dan Pengembangannya. Penerbit Kanisius. Yogyakarta.

Utomo WH 2010. Agroforestry: hidup layak berkesinambungan pada lahan sempit. Prosiding Tekanan Penduduk, Degradasi Lingkungan dan Ketahanan Pangan. IPB Bogor.

Widianto, Kurniatun H, Didik S, Mustofa AS 2003. Bahan ajaran agroforestri 3: fungsi dan peran agroforestri. Bogor: World Agroforestry Centre (ICRAF).

Yulianti T 2010. Bahan organik: perannya dalam pengelolaan kesehatan tanah dan pengendalian patogen tular tanah menuju pertanian tembakau Organik. Bul. Tan. Tembakau, Serat dan Minyak Industri 2(1), April 2. 